\title{
The Effect of the Increase in General Surgery Residency Openings in Brazil
}

\section{O Reflexo do Aumento de Vagas da Residência de Cirurgia Geral no Brasil}

\author{
Antoninho José Tonatto Filho ${ }^{1}$ (D) \\ Felipe Melloto Gallotti ${ }^{\mathrm{I}}$ iD \\ Alberto Treiguer ${ }^{\mathrm{I}}(\mathbb{D}$ \\ José Gustavo Olijnyk ${ }^{\mathrm{I}}$ D \\ Thiago Kreutz Grossmann ${ }^{\mathrm{I}}$ (D) \\ Thiago Filomena Lombard' ${ }^{1} \mathbb{D}$
}

\section{KEYWORDS}

- Medical Residency.

- Video-assisted Surgery.

- General Surgery.

Introduction: In recent years, there has been an increase in the number of medical residency programs in all regions of Brazil, only in the last 4 years, from 2014 to 2018, there was an increase from 18,953 general spots offered for the first year of medical residency to 26,094, 37\% more, this was also observed in General Surgery Residencies around Brazil. As a result, the number of general surgeons has increased substantially, from 12,430 in 2008 to 34,065 in 2018, an absolute percentage increase of 174\%. These new surgeons are bringing with them their theoretical and practical knowledge already updated, regarding new techniques and surgical modalities. In this context, in the last 2 decades, video-assisted surgery has become the choice for numerous procedures in Brazil and in the World, considering its benefits for patients, such as less postoperative hospital stay and less metabolic response to surgical trauma, for example. The current study correlates the data between the increase in the number of spots in medical residency programs, related to the graduation of new surgeons in Brazil, to the increase of videolaparoscopic surgeries in the public health system. Methodology: Review and online analysis of the national electronic public health registry database - DATASUS. The most performed Surgeries in Brazil were chosen for our data analysis. Results: The results were divided into five geographically distributed areas in Brazil. At the end of the current study, the number of video-assisted surgeries increased by 233\%, accompanied by a $63 \%$ increase in the number of medical residency openings and a $174 \%$ absolute increase in the number of new surgeons in Brazil at the same period. Conclusion: The current study showed that the increase in the number of video-assisted surgeries in the country is related to the exponential increase in the number of medical residency spots and, consequently, to the number of new graduated general surgeons. This increase occurs more and more in a context of videolaparoscopic techniques, revealing multiple benefits already recognized for patients. We could conclude, therefore, that the increase in the number of medical residencies in general surgery - which are increasingly teaching videolaparoscopic techniques - has contributed as a complementary factor to the increase in the number of video-assisted surgeries observed in all regions of Brazil. 


\section{RESUMO}

\section{PALAVRAS-CHAVE}

- Residência Médica.

- Cirurgia Videoassistida.

- Cirurgia Geral

Introdução: Nos últimos anos, houve um aumento no número de vagas de residência médica em todas as regiões do Brasil. Apenas nos últimos quatro anos, de 2014 a 2018, houve um aumento de 18.953 vagas gerais ofertadas para o primeiro ano de residência médica para 26.094, 37\% a mais, o que foi acompanhado também pela área de cirurgia geral. Em consequência, o número de cirurgiões gerais vem aumentando substancialmente, de 12.430 em 2008 para 34.065 em 2018, um aumento percentual absoluto de 174\%. Esses novos cirurgiões vêm trazendo consigo seus conhecimentos teóricos e práticos já atualizados, em sua maioria, de novas técnicas e modalidades cirúrgicas. Nesse contexto, nas últimas duas décadas a cirurgia videoassistida vem se tornando a via de escolha para inúmeros procedimentos no Brasil e no mundo, tendo em vista seus benefícios para os pacientes, tais como menor permanência hospitalar no pós-operatório e menos resposta metabólica ao trauma cirúrgico. Este estudo correlaciona o aumento do número de vagas em residência médica e consequentemente de novos cirurgiões ao aumento de cirurgias videolaparoscópicas no sistema público de saúde. Metodologia: Os dados para revisão foram extraídos do Departamento de Informática do Sistema Único de Saúde (Datasus). Escolheram-se as cirurgias com maior frequência para análise dos dados. Resultados: Os resultados foram divididos nas cinco áreas geograficamente distribuídas pelo Brasil. Ao final do estudo atual, demonstrou-se que o número de cirurgias videoassistidas aumentou em 233\%, acompanhado pela elevação de $63 \%$ no número de vagas de residência médica e acréscimo de $174 \%$ no número de novos cirurgiões no Brasil, no mesmo período. Conclusão: $O$ atual estudo demonstrou que o aumento do número de cirurgias videoassistidas no país está relacionado diretamente com o aumento exponencial do número de vagas de residência médica e, por consequência, do número de novos cirurgiões gerais. A formação desses novos cirurgiões gerais ocorre, cada vez mais, num contexto de técnicas videolaparoscópicas que trazem consigo inúmeros benefícios já reconhecidos para os pacientes. Conclui-se, portanto, que o acréscimo no número de vagas de residências médicas em cirurgia geral - que cada vez mais empregam os ensinamentos em técnicas videolaparoscópicas - tem contribuído como fator complementar para o aumento do número de cirurgias videoassistidas observado em todas as regiões do Brasil.

Recebido em 31/7/19

Aceito em 8/10/19

\section{INTRODUCTION}

In 1889, surgeon William Stewart Halsted had the idea of implementing the first professional training program in hospital service, at Johns Hopkins Hospital, where he became the Head of the Service in the following year ${ }^{1}$. He realized that teaching surgery at the time, carried out through direct exposure to medical practice (classic practice: traineemaster) was flawed and inefficient. From then on he created new methods for specialized, supervised and more effective training, which he called "Residency", because the doctors actually lived in the hospital.

The history of Medicine and Surgery in Brazil (BR) effectively begins with the arrival of the Portuguese Royal Family, in 1808. It started with Dr. José Correia Picanço, head-surgeon of the Kingdom, trained by the Medical School of Montpelier, who helped D. João VI with the first medical school in Brazil (BR), the Anatomical-Surgical and Medical School of Bahia, opened in 1808, in Salvador, currently the School of Medicine of the Federal University of Bahia. In the same year, the School of Anatomy, Medicine and Surgery of Rio de Janeiro was established, which later became the University of BR and is now the School of Medicine of the Federal University of Rio de Janeiro. University teaching had started in $\mathrm{BR}^{1,2}$.

As it happened in the United States, around the 1950s in BR, medical training was questioned, when Prof. Mariano de Andrade, at the Hospital dos Servidores do Estado, in Rio de Janeiro, and Prof. Alípio Correa Neto, at Hospital de Clínicas in São Paulo, devised the first medical residency (MR) programs in General Surgery (GS) in Brazil. Since then, the number of MR programs in GS has increased, and there has been a constant improvement, not only regarding the structure of the residency hospitals, but also regarding the teaching methods, methodology, together with the globalization of information and new techniques that were incorporated into the residency programs and taught to new surgeons.

It can be said that video-assisted surgery has also exhibited the same phenomenon in the last 30 years in BR. This occurs not only in private hospitals, but also in public ones, where increasingly more minimally invasive techniques have been adopted as the method of choice, following the tendency of developed countries.

The aim of this study is to correlate whether the increase in the number of MR program openings in GS in BR and, consequently, of new surgeons has contributed to the increase in the number of video-assisted surgeries in the Brazilian Unified Health System (SUS, Sistema Unico de Saúde), especially videolaparoscopic cholecystectomy (since this is the most frequently video-assisted surgery performed in BR), and the fact that the authors believe there is a correlation between these data.

\section{METHOD}

A cross-sectional study was carried out with an analysis of prevalence of laparoscopic cholecystectomy (LC) and open cholecystectomy (OC) from the years 2008 to 2017. Subsequently, these data were compared to the number of $\mathrm{MR}$ openings in $\mathrm{BR}$ and the number of surgeons in the country. The data were taken from DATASUS ${ }^{3}$ (national public health registry database), considering that the facilities that are part of SUS must issue a Hospital Admission Authorization (HAA) related to hospitalization

REVISTA BRASILEIRA DE EDUCAÇÃO MÉDICA

2 44 (1) : e007; 2020 
for the indicated surgical procedure and subsequent billing of costs to be paid by the government.

Data were collected on January 13, 2019, following the steps below: in the DATASUS website, the Health Information chapter (TABNET) was accessed to obtain the number of procedures performed since 2008 . Subsequently, to generate an information table from each period, the procedures related to the study were selected - with the lines corresponding to the $\mathrm{BR}$ regions and the columns to the years of processing. Only approved HAA were used as this study data. Then, the data analysis time was delineated, including data from January 2008 to December 2017.

The number of MR openings in $\mathrm{BR}$ was obtained through the Ministry of Education (MEC) ${ }^{4}$ while the number of general surgeons in Brazil was obtained through the Federal Council of Medicine (CFM) ${ }^{5}$ and Medical Demography in Brazil, by Scheffer $\mathrm{M}^{6,7,8}$.

\section{RESULTS}

As for MR in GS, it can be observed that 1,148 openings were offered for the first year (R1) in 2008, whereas in 2018 the number increased to 1,876 openings, an increase of $63 \%$. Regionally, the North $(\mathrm{N})$ region showed the largest increase (85\%), followed by the South (S) (69\%), Midwest (MW) (68\%), Northeast (NE) (63\%) and Southeast (SE) (58\%) regions. The SE region had the highest absolute number, with 1,024 openings.

The $\mathrm{N}$ region also showed the greatest increase in the number of surgeons (308\%), followed by the NE (304\%), SE (206\%), MW (204\%) and $\mathrm{S}(85 \%)$ regions. The highest absolute number again was found in the SE region, with 17,401 surgeons in 2018.

The LCs, which represented only $12 \%$ of cholecystectomies (CT) in 2008, increased to $40 \%$ in 2017. Table 1 shows that the greatest increase in the period occurred in the MW region (760\%) region, followed by the NE (380\%), SE (243\%), N (233\%) and S (73\%) regions. The highest absolute number again was observed in the SE region, with 43,307 procedures in 2007 and the highest percentage rate of $\mathrm{LC}$, with $55 \%$ of the CTs performed by this route.

\section{DISCUSSION}

In the last 10 years, there has been an increase in the number of laparoscopic surgeries in all regions of the country, accompanied by an increase in the total number of newly graduated general surgeons and an increase in the number of medical residency openings. The total number of LCs, the most frequently performed video-assisted procedure in the country, went from 19,277 in 2008 , to 81,072 in 2017 , while the increase in the number of surgeons during the same period was $174 \%$, and of the openings in GS, 63\%. As shown in Table 2, the regions show a pattern of proportional increase in the number of videolaparoscopies, as there was an increase in the number of MR openings in their regions and, consequently, of new general surgeons. The positive data is found in the MW region, which despite having the $3^{\text {rd }}$ highest increase in openings $(68 \%)$, and the $4^{\text {th }}$ highest increase in new surgeons $(204 \%)$, showed the highest percentage increase in LC (760\%). The $\mathrm{N}$ region, on the other hand, which had the largest increase in MR openings (85\%), and the highest increase in new surgeons in the period (308\%), showed only the $4^{\text {th }}$ highest increase in LC $(233 \%)$. The SE region had the highest absolute number of MR openings in GS, number of surgeons, procedures performed per year and percentage of LC compared to OC. There was no decrease in both the number of MR openings, the number of absolute surgeons per region, as well as significant increases in the number of LCs across the country, with no decreases in any region of the country.

When analyzing the data, one can infer that there was an association between the increase in MR openings and the consequent increase in new general surgeons, with the increase in LC per region. However, as we can see in the $\mathrm{N}$ and MW regions, these should not be considered as isolated factors for an increase in the number of LC.

Among the explanations for the increase in the number of laparoscopic surgeries, we highlight the shorter length of hospital stay, lower rate of postoperative pain, smaller surgical incisions - which leads to a more favorable aesthetic result -the lower complication rate, and early return to work. Such aforementioned reasons make laparoscopy gain a prominent role and become the method of choice for many GS professionals and services.

It should be noted that the increase in the number of MR openings is only one of the relevant factors that led to an increase in the number of video-assisted surgeries in BR. We can consider that the improvement in the hospital structures and the diffusion of videolaparoscopic materials, mainly in the countryside regions, were crucial to this process. However, the lower numbers of video-assisted surgeries are analyzed in cities without adequate infrastructure, which again indicates the need for greater investments in technologies.

\begin{tabular}{|c|c|c|c|c|c|c|}
\hline \multicolumn{7}{|c|}{$\begin{array}{l}\text { Table } 1 \\
\text { holecystectomies performed in Brazil by region } \\
\text { [Source: DATASUS }]^{3}\end{array}$} \\
\hline \multirow{2}{*}{ Region } & \multicolumn{3}{|c|}{2008} & \multicolumn{3}{|c|}{2017} \\
\hline & OC & LC & $T x$ & OC & LC & $\mathbf{T x}$ \\
\hline North & 9,821 & 346 & 3 & 14,081 & 1,636 & 10 \\
\hline Northeast & 36,383 & 2,159 & 5 & 37,959 & 12,576 & 24 \\
\hline Southeast & 50,675 & 9,305 & 16 & 34,896 & 43,307 & 55 \\
\hline South & 22,049 & 6,671 & 23 & 23,217 & 16,094 & 40 \\
\hline Midwest & 11,262 & 796 & 5 & 9,881 & 7,459 & 43 \\
\hline & 130,190 & 19,277 & 12 & 120,034 & 81,072 & 40 \\
\hline
\end{tabular}

OC: open cholecystectomy, LC: laparoscopic cholecystectomy, Tx laparoscopic cholecystectomy index

\begin{tabular}{|c|c|c|}
\hline \multicolumn{3}{|c|}{$\begin{array}{c}\text { Table } 2 \\
\text { Medical residency openings/year x Region (Source: MEC) }{ }^{4}\end{array}$} \\
\hline Regions & $\begin{array}{l}\text { General Surgery } \\
\text { Openings - } 2008\end{array}$ & $\begin{array}{l}\text { General Surgery } \\
\text { Openings - } 2018\end{array}$ \\
\hline North & 55 & 102 \\
\hline Northeast & 166 & 272 \\
\hline Midwest & 88 & 148 \\
\hline Southeast & 647 & 1,024 \\
\hline South & 195 & 330 \\
\hline Brazil & 1,148 & 1,876 \\
\hline
\end{tabular}

REVISTA BRASILEIRA DE EDUCAÇ̃̃o MÉDICA

3 44 (1) : e007; 2020 


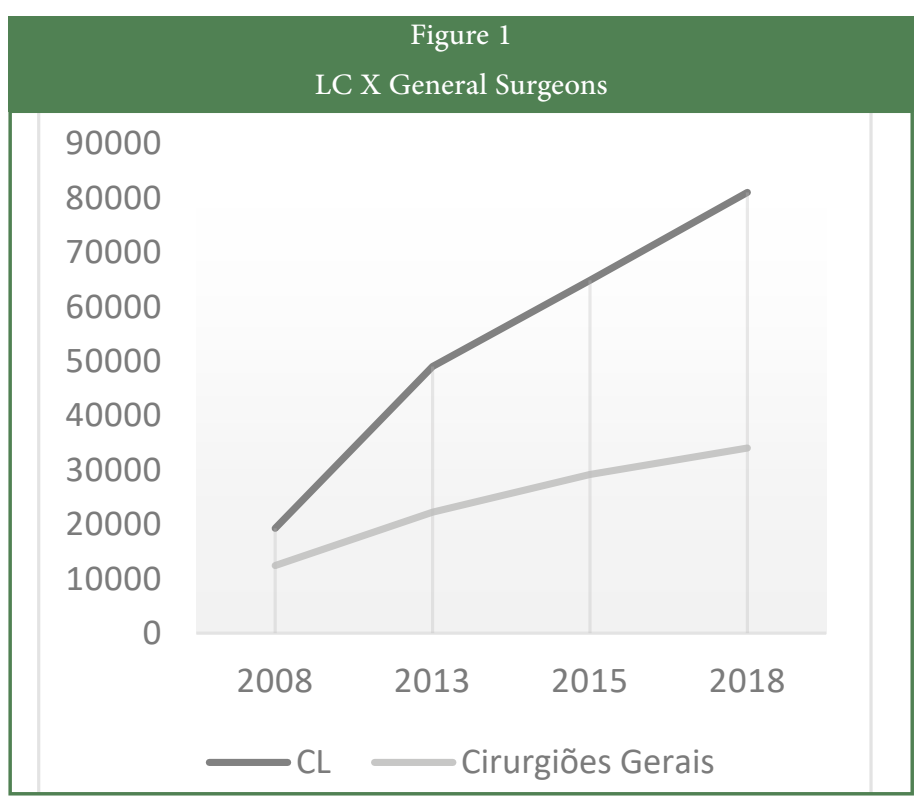

When we analyzed the possibility of an increase in biliary lesions due to the increase in the number of LCs, there was, at the beginning of the use of the method, a 2 to 3 -fold increase in iatrogenic lesions of the bile ducts when compared to the open technique. Early identification of biliary injury is extremely important for its treatment; however, less than half of cases are diagnosed early, resulting in severe late complications, such as biliary cirrhosis, liver failure and death. With the increase in the number of procedures, increase in the surgeons' experience and the improvement of the materials and quality of the video images, the lesions in the bile ducts were reduced to $0.1-0.4 \%$ of the $\mathrm{LCs}^{9,10}$.

Recent reports by the World Health Organization on safety and quality of performance in surgery, have emphasized the urgent need to improve training, evaluation and accreditation for technologicallydependent surgical procedures, such as in video-surgery ${ }^{11}$.

In $\mathrm{BR}$, there is a great deficit in video-surgery development and training in the different surgical specialties ${ }^{12}$, and our survey shows that, despite the advances in the country, we are still far from the situation in developed countries. This fact shows that the teaching of video-surgery in BR has not been able to educate well-trained professionals, capable of safely performing procedures using this method. This can be attributed to several factors: 1) surprising lack of information about the method even by medical specialists; 2) professional context of socioeconomic deterioration of the physician, discouraged from investing in refreshing courses; 3 ) high cost of equipment, often paid for by the doctors themselves, in health insurance medicine or medical care provided by SUS, which does not pay enough to allow large investments; 4) lack of organizational and structural "know-how" about the method, which makes professional initiation and development very difficult; 5) surgeons' self-sufficiency and conservatism, with the maintenance of old "surgical dogmas"; 6) qualitative and quantitative deficiencies in MR courses and programs; 7) specific technical aspects of learning that determine educational difficulties of complex resolution; 8) disconnection of the method's evolutionary process between surgical specialties that repeat the difficulties already overcome by the others; 9) lack of the development of "surgical schools" aimed at video-surgery" Moreover, preceptorship and the volume of video-surgical procedures also contribute to this scenario ${ }^{13}$. These facts are harmful to patients, surgeons and the concept of the method in relation to the scientific community and the population in general ${ }^{12,13,14}$.

In the era of minimally-invasive procedures, particularly those performed by video-surgery, psychomotor learning should not and cannot be developed directly in the patient. It must be performed through surgical simulation and, whether in organic, inorganic or virtual models, must precede the stage of training in the surgical field in humans. Surgical training must move from a "Halstedian" model ("see one, do one, teach one") to a model determined by simulation ("do many, mentored always") ${ }^{15}$.

As models, we have in Europe the "Laparoscopic Surgical Skills Programme" (LSS), a project of the European Society of Endoscopic Surgery, which is a multi-level curriculum platform for education and training in video-surgery ${ }^{16}$. In North America, the most frequently used system is the "Fundamentals in Laparoscopic Surgery" (FLS) developed by the leaders of the American Society of Endoscopic Gastrointestinal Surgery and also approved by the American College of Surgeons ${ }^{17,18}$.

In $\mathrm{BR}$, there is a gap for these models, for the creation of more training centers, better equipped both from a human and structural point of view, of a permanent character, with longer-term teaching projects, consistent from the pedagogical point of view, with greater emphasis on organizational guidance and tutorial support. The development of "videosurgeon training schools" should be encouraged ${ }^{12}$.

One bias that we highlight in the present study is that only data related to videolaparoscopic surgeries performed in the Unified Health System were collected through DATASUS, not including surgeries carried out through the private health care system and health plans, for which we did not find concrete data; nevertheless, it has already been observed that the private health care segment in BR has an absolute predominance of LC over OC during the entire period ( $90 \%$ or more of the total). Also considering that $75.7 \%$ of the Brazilian population does not have private health insurance ${ }^{19}$ and theoretically it would be covered by SUS alone, such information reflects with good precision the numbers of public health in BR.

\section{CONCLUSION}

We can conclude, with the data obtained in this survey, that there is an association between the increase in the number of MR openings and the increase in the number of video-assisted surgeries in BR, mainly within the scope of SUS. This increase was not only evident in the main centers of the country, but was also observed in the countryside, regions that are generally more lacking in resources and new technologies. This is only one of the factors that may be contributing to this increase in laparoscopic surgeries. However, the data is still far from the reality of developed countries or even the private health care system in BR. Changes must be made in the teaching of GS MR through more efficient pedagogical processes, so that future surgeons can combine their best qualification with good working conditions and can increasingly apply new video-assisted techniques in the national territory for the benefit of patients.

\section{REFERENCES}

1. Santos EG. Residência médica em cirurgia geral no Brasil - muito distante da realidade profissional. Rev Col Bras Cir 2009 Jul;36(3):271276 [acesso em 15 jan 2019]. Disponível em: http://www.scielo.br/ 
scielo.php?script=sci_arttext\&pid=S0100-69912009000300017\&lng=p t\&tlng=pt.

2. Amaral JL. Duzentos anos de ensino médico no Brasil. Rio de Janeiro. Tese [Doutorado em saúde coletiva] - Universidade do Estado do Rio de Janeiro; 2007.

3. Brasil. Ministério da Saúde. Datasus - Procedimentos hospitalares do SUS por local de internação [acesso em 2 jan 2019]. Disponível em: http://tabnet.datasus.gov.br/cgi/deftohtm.exe?sih/cnv/qiuf.def.

4. Brasil. Ministério da Educação Comissão Nacional de Residência Médica [acesso em 2 jan. 2019]. Disponível em: https://www.mec.gov. br/.

5. Conselho Federal de Medicina. Demografia médica [acesso em 2 jan 2019]. Disponível em: https://portal.cfm.org.br/

6. Scheffer M. Demografia médica no Brasil 2018. São Paulo: FMUSP, CFM, Cremesp; 2018.

7. Scheffer M. Demografia médica no Brasil 2015. São Paulo: Departamento de Medicina Preventiva, Faculdade de Medicina da USP, Conselho Regional de Medicina do Estado de São Paulo, Conselho Federal de Medicina; 2015.

8. Scheffer M. Demografia médica no Brasil 2013. São Paulo: Departamento de Medicina Preventiva, Faculdade de Medicina da USP, Conselho Regional de Medicina do Estado de São Paulo, Conselho Federal de Medicina; 2013.

9. Strasberg SM, Hertl M, Soper NJ. Na analysis of the problem of biliary injury during laparoscopic cholecystectomy. J Am Coll Surg 1995 Jan;180(1):101-25.

10. Buzink S, Fingerhut A, Hanna G, Jakimowicz J, Radonak J, Soltes M. Laparoscopic Surgical Skills programme: preliminary evaluation of Grade I Level 1 courses by trainees. Wideochir Inne Tech Malo Inwazyjne 2012;7(3):188-92.

11. Nácul MP, Cavazzola LT, Melo MC. Aspectos atuais do ensino da videocirurgia no Brasil - uma análise crítica [editorial]. Rev Bras Videocir 2004;2(1):1-4.

12. Nácul MP, Cavazzola LT, Melo MC. Situação atual do treinamento de médicos residentes em videocirurgia no Brasil: uma análise crítica. ABCD Arq Bras Cir Dig 2015;28(1):81-5.

13. Nácul MP. Conceitos e estado da arte da videocirurgia. Rev Saúde UCPEL 2007;1(2):149-59.
14. Satava R. Emerging trends that Herald the future of surgical simulation. Surg Clin North Am 2010;90(3):623-33.

15. Laparoscopic Surgery Skills [homepage da internet]. LSS Foundation 2014 [citado em 10 de julho 2014]. Disponível em: http://www.lsssurgical.eu/nl/pages/home. Acesso em 19 de setembro de 2014.

16. Integrating advanced laparoscopy into surgical residency training. Society of American Gastrointestinal Endoscopic Surgeons (SAGES). Surg Endosc 1998;12(4):374-6.

17. Okrainec A, Fried GM, Soper NJ, Swanstrom LL. Trends and results of the first 5 years of Fundamentals of Laparoscopic Surgery (FLS) certification testing. Surg Endosc 2011;25(4):1192-8.

18. Agência Nacional de Saúde Suplementar [acesso em 30 jan. 2019]. Disponível em: http://www.ans.gov.br/perfil-do-setor/dados-gerais.

\section{AUTHORS' CONTRIBUTION}

Antoninho José Tonatto Filho: Conceptualization; Data curation; Formal analysis; Methodology; Papers / Writing - Original draft.

Felipe Melloto Gallotti: Conceptualization; Data curation; Formal analysis; Methodology; Papers /Writing - Original draft.

Alberto Treiguer: Conceptualization; Data curation; Formal analysis; Methodology; Papers / Writing - Original draft; Supervision.

José Gustavo Olijnyk: Formal analysis; Supervision; Writing proofreading and editing.

Thiago Kreutz Grossmann: Methodology; Supervision; Writing proofreading and editing.

Thiago Filomena Lombard: Methodology; Supervision; Writing proofreading and editing.

\section{CONFLICTS OF INTEREST}

The authors declare no conflicts of interest.

\section{ADDRESS FOR CORRESPONDENCE}

Felipe Melloto Gallotti

Avenida Benno Mentz, n 100, apartamento 903B, Porto Alegre, RS, Brazil. E-mail: felipe_gallotti@hotmail.com 